\title{
PENDAFTARAN TANAH PERTAMA KALI SECARA SPORADIK MELALUI PENGAKUAN HAK
}

\author{
Oleh \\ Bambang Eko Muljono \\ Dosen Fakultas Hukum Universitas Islam Lamongan
}

\begin{abstract}
ABSTRAK
Pasal 19 Undang-Undang Nomor 5 Tahun 1960 Tentang Peraturan Dasar Pokok-Pokok Agraria menegaskan bahwa untuk menjamin kepastian hukum oleh Pemerintah diadakan pendaftaran tanah diseluruh wilayah Republik Indonesia menurut ketentuan-ketentuan yang diatur dengan Peraturan Pemerintah. Peraturan Pemerintah sebagai pelaksana dari amanat yang ditetapkan dalam pasal 19 ini adalah PP Nomor 24 Tahun 1997 yang menggantikan PP nomor 10 Tahun 1961. Kegiatan pendaftaran tanah yang dilakukan melalui Pendaftaran Tanah Pertama Kali Secara Sistematik dan Sporadik. Mengingat pentingnya sertipikat hak milik sebagai surat tanda bukti hak yang berlaku sebagai alat pembuktian yang kuat maka penulis tertarik untuk meneliti syarat, pelaksanaan dan bagaimana kekuatan dan kepastian hukum sertipikat yang diterbitkan melalui Pengakuan Hak dalam kegiatan Pendaftaran Tanah Pertama Kali Secara Sporadik. Penelitian ini bersifat deskriptif komparatif. Jenis penelitian yang digunakan melalui pendekatan kualitatif, sedangkan untuk mendukung penelitian dilakukan observasi dan wawancara. Bahan utama dari penelitian ini adalah data kepustakaan dan data empiris yang terlebih dahulu dilakukan pemeriksaan, pengelompokan, pengolahan, dan kemudian dievaluasi sehingga diketahui validitasnya, lalu dianalisis menggunakan metode analisis kualitatif dengan logika deduksi dengan menggunakan perangkat normatif. Dari kegiatan interprestasi data kepustakaan maupun data empiris yang diperoleh, diharapkan dapat menghasilkan kesimpulan yang sesuai dengan permasalahan dan tujuan penelitian Hasil penelitian menunjukkan bahwa melalui lembaga konversi, hak-hak atas tanah yang ada sebelum berlakunya UUPA disesuaikan dengan hak yang ada di UUPA. Proses pendaftaran tanahnya dilaksanakan dalam kegiatan Pendaftaran Tanah Pertama Kali secara Sporadik, sedangkan proses penerbitan sertipikatnya dilakukan melalui penegasan konversi dan/atau pengakuan hak sebagaimana disebut pada pasal 88 PMNA/KBPN Nomor 3 Tahun 1997.
\end{abstract}

Kata Kunci : UUPA, Pendaftaran Tanah Pertama Kali.

\subsection{PENDAHULUAN}

\section{Latar Belakang}

Filosofis lahirnya Undang Undang Republik Indonesia Nomor 5 Tahun 1960 tentang Peraturan Dasar Pokok-pokok Agraria (selanjutnya disebut UUPA) dilandaskan kepada kondisi adanya hukum agraria yang berlaku tersusun berdasarkan tujuan dan sendi-sendi pemerintah jajahan. Kondisi ini juga menimbulkan berlakunya hukum agraria yang prularis yaitu masih berlakunya hukum adat tanah disamping hukum tanah barat berdasarkan ketentuan konkordansi masa itu. Dengan kondisi yang demikian dirasakan dalam kegiatan agraria tidak terdapat jaminan kepastian hukum.

Berdasar latar belakang di atas maka diperlukan hukum agraria yang bersifat nasional dan menghilangkan prularisme sehingga dapat memberikan jaminan kepastian hukum dalam lapangan agraria, maka lahirlah Undang Undang Republik Indonesia Nomor 5 Tahun 1960 tentang Peraturan Dasar Pokok-pokok Agraria sebagai landasan 
yuridis bagi kebijakan bidang pertanahan di Indonesia, yang menetapkan dan memberikan arah pengaturan terhadap penjabaran Pasal 33 ayat (3) Undang Undang Dasar 1945. UUPA merupakan Undangundang yang secara eksplisit menjabarkan prinsip-prinsip dasar dan jiwa Pancasila serta UUD 1945 di dalam pasal-pasalnya.

UUPA selain merupakan hukum publik juga menyangkut hukum privat karena UUPA merupakan pengganti Buku II Kitab Undang-undang Hukum Perdata. Dalam kaitannya dengan aspek-aspek keperdataan, hasil kegiatan pertanahan mempunyai akibat hukum sehingga produk-produk yang dihasilkan harus sesuai dengan ketentuan yang berlaku saat ini, yaitu ketentuan-ketentuan yang diatur dalam UUPA dan peraturan pelaksanaannya. Badan Pertanahan Nasional sebagai lembaga pemerintah yang diberi otoritas di bidang pertanahan, berwenang untuk menetapkan hubungan hukum antara obyek dan subyek hak atas tanah. Penciptaan hubungan hukum tersebut dilakukan dengan prosedur mekanisme peraturan perundang-undangan yang berlaku di bidang pertanahan yang implementasi pelaksanaan seluruhnya merupakan produk Badan Pertanahan Nasional yang bersifat penetapan ( beschikking ).

Sebagaimana diketahui sebelum berlakunya UUPA, berlaku bersamaan dua perangkat hukum tanah di Indonesia (dualisme). Satu bersumber pada hukum adat disebut hukum tanah adat dan yang lain bersumber pada hukum barat disebut hukum tanah Barat. Dengan berlakunya hukum agraria yang bersifat nasional (UUPA) maka terhadap tanah-tanah dengan hak barat maupun tanah-tanah dengan hak adat harus dicarikan padanannya di dalam UUPA. Untuk dapat masuk ke dalam sisem dari UUPA diselesaikan dengan melalui lembaga konversi.
A.P.Parlindunga menyatakan bahwa Konversi adalah pengaturan dari hak-hak tanah yang ada sebelum berlakunya UUPA untuk masuk dalam sistem dari UUPA. ${ }^{1}$ Sedangkan Boedi Harsono menyatakan bahwa Konversi adalah perubahan hak yang lama menjadi satu hak yang baru menurut UUPA. $^{2}$ Terhadap pelaksanaan konversi, ada 3 (tiga) cara dalam pendaftaran tanahnya, yakni :

1. Dikonversi menjadi hak milik apabila bukti kepemilikannya ada sejak berlakunya UUPA, misalnya hak gogolan yang bersifat tetap

2. Penegasan Hak untuk tanah-tanah yang tunduk kepada Hukum Adat tetapi tidak terdaftar dalam ketentuan konversi sebagai tanah yang dapat dikonversikan kepada sesuatu hak atas tanah menurut ketentuan UUPA, tetapi diakui tanah tersebut sebagai hak adat,

3. Pengakuan hak, untuk atas tanahtanah yang tidak ada atau tidak ada lagi tanda bukti haknya.

Mengamati perkembangan masalah pertanahan dalam kurun waktu 55 tahun sejak diundangkannya Undang Undang Nomor 5 Tahun 1960, masalah pertanahan telah menjadi masalah lintas sektoral yang menyangkut seluruh aspek kehidupan. Dalam konteks demikian, tanah bersifat multidimensional yaitu dimensi fisik, kimia, biologi, sosial, ekonomi, politik dan magis religius yang masing-masing berpotensi memberikan kesejahteraan bagi ummat manusia.

Kepastian hukum atas tanah merupakan salah satu tujuan dari UUPA, hal ini sesuai dengan pasal 19 ayat (1) yang berbunyi " Untuk menjamin kepastian hukum oleh Pemerintah diadakan Pendaftaran Tanah di seluruh wilayah Republik Indonesia menurut ketentuan ketentuan yang diatur dengan Peraturan Pemerintah". Ketentuan pasal 19 ini menegaskan bahwa kepastian hukum tersebut meliputi: ${ }^{3}$ 
1. Kepastian hukum mengenai subyek hukum hak atas tanah (orang/badan hukum );

2. Kepastian mengenai letak, batas, ukuran / luas tanah atau kepastian mengenai obyek hak;

3. Jenis / macam hak atas tanah yang menjadi landasan hubungan hukum antara tanah dengan orang / badan hukum.

Para ahli pendaftaran tanah menyatakan bahwa dalam mendaftarkan tanah akan menghadapi banyak masalah, antara lain: ${ }^{4}$

1. Masalah alat pembuktian pemilikan tanah

2. Masalah belum tersedianya kerangka dasar teknis, peta dasar, terutama peta kadasteral.

3. Masalah birokrasi

Untuk mengatasi masalahmasalah ini telah diterbitkan Peraturan Pemerintah Nomor 24 Tahun 1997 tentang Pendaftaran Tanah ( selanjutnya disebut P.P. Nomor 24 Tahun 1997) yang mulai berlaku tanggal 8 Oktober 1997 dan merupakan peraturan pelaksanaan ( law enforcement ) pasal 19 UUPA sebagai pengganti Peraturan Pemerintah Nomor 10 Tahun 1961 yang selama ini menjadi dasar pelaksanaan pendaftaran tanah di Indonesia.

Ditetapkannya P.P. Nomor 24 Tahun 1997 tersebut merupakan salah satu upaya pemerintah untuk menyediakan dasar hukum yang kuat bagi pemberian kepastian hukum yang disesuaikan dengan kebutuhan dan perkembangan masyarakat serta pembangunan dan dalam pelaksanaannya diarahkan untuk memudahkan pelayanan yang cepat, murah namun tetap menjamin kepastian hukum guna mewujudkan keadilan sosial bagi seluruh rakyat Indonesia.

Program keagrariaan yang sampai sekarang belum dapat diselesaikan secara tuntas adalah pendaftaran tanah, padahal dalam masyarakat madani, kepastian hak-hak atas tanah bagi masyarakat merupakan syarat utama.

Hal ini disebabkan masih adanya anggapan bahwa untuk mendapatkan sertipikat tanah harus melalui prosedur yang berbelit-belit, biaya yang besar serta waktu yang lama, beban ini semakin berat dirasakan khususnya bagi golongan ekonomi lemah, akibatnya masyarakat enggan untuk mensertipikatkan tanahnya sedangkan di lain pihak tuntutan kemajuan jaman adalah segera merealisasi proses pendaftaran tanah secara merata.

Upaya konkrit pemerintah dalam percepatan pendaftaran tanah adalah kerja sama dengan Bank Dunia dan AusAID membiayai proyek besar Land Administration Project ( LAP ) atau disebut juga Proyek Administrasi Pertanahan ( Loan IBRD Nomor 3792IND) yang dimulai sejak tahun $1994 .^{\mathbf{5}}$

Percepatan pendaftaran tanah juga dilakukan oleh pemerintah dengan dana yang bersumber pada Daftar Isian Pelaksanaan Anggaran (DIPA) Badan Pertanahan Nasional, melalui kegiatan Proyek Operasi Nasional Agraria (PRONA), program sertipikasi Masyarakat Berpenghasilan Rendah (MBR) dan program sertipikasi Tanah Nelayan.

Selain itu, dalam rangka mendukung program percepatan pendaftaran tanah, Kantor Pertanahan Kabupaten Lamongan juga melakukan kerjasama dengan Perusahaan Daerah Bank Daerah Lamongan melaksanakan program Sertipikat Massal Swadaya.

Dalam P.P. Nomor 24 Tahun 1997, pada pasal 13 ayat (1) disebutkan bahwa Pendaftaran tanah untuk pertama kali dilaksanakan melalui pendaftaran tanah secara sistematik dan pendaftaran tanah secara sporadik. Selanjutnya pada pasal 13 ayat (4) disebutkan bahwa Pendaftaran tanah secara 
sporadik dilaksanakan atas permintaan pihak yang berkepentingan.

Definisi Pendaftaran Tanah Secara Sporadik menurut P.P. Nomor 24 Tahun 1997 pasal 1 angka 11 adalah kegiatan pendaftaran untuk pertama kali mengenai satu atau beberapa objek pendaftaran tanah dalam wilayah atau bagian wilayah suatu desa/kelurahan secara individual atau massal.

Dengan berlakunya PP No. 24 tahun 1997 ini diharapkan permasalahan tentang informasi mengenai pertanahan ini dapat dihindarkan kekurangan atau tidak adanya jelasnya status kepemilikan (hak-hak atas tanah) yang ada, agar terwujud tujuan dari UUPA yaitu kepastian hukum hak atas tanah dan terwujudnya unifikasi hukum pertanahan di Indonesia.

Selanjutnya, sebagai pelaksanaan dari PP No. 24 Tahun 1997, pemerintah menerbitkan Peraturan Menteri Negara Agraria Nomor 3 Tahun 1997 tentang Ketentuan Pelaksanaan Peraturan Pemerintah Nomor 24 Tahun 1997 tentang Pendaftaran Tanah (selanjutnya disebut PMNA/KBPN Nomor 3 Tahun 1997).

Sebagaimana disebutkan dalam pasal 13 ayat (4) PP No. 24 tahun 1997, pada pasal 73 ayat (1) PMNA/KBPN Nomor 3 Tahun 1997 juga disebutkan bahwa kegiatan pendaftaran tanah secara sporadik dilakukan atas permohonan yang bersangkutan. Sedangkan proses penerbitan sertipikatnya dilakukan melalui penegasan konversi dan/atau pengakuan hak sebagaimana disebut pada pasal 88 PMNA/KBPN Nomor 3 Tahun 1997.

Penegasan konversi diberikan jika hak atas tanah yang alat bukti tertulisnya lengkap sebagaimana dimaksud dalam pasal 76 ayat (1) dan yang alat bukti tertulisnya tidak lengkap tetapi ada keterangan saksi maupun pernyataan yang bersangkutan sebagaimana dimaksud dalam Pasal 76 ayat (2) dan tanahnya dikuasai oleh pemohon atau oleh orang lain yang disetujui oleh pemohon, oleh Kepala Kantor Pertanahan ditegaskan konversinya menjadi hak milik dengan nama pemegang hak yang terakhir, Sedangkan untuk Pengakuan Hak, jika alat bukti kepemilikannya tidak ada tetapi telah dibuktikan kenyataan penguasaan fisiknya selama 20 tahun sebagaimana dimaksud dalam Pasal 76 ayat (3) oleh Kepala Kantor Pertanahan diakui sebagai Hak Milik.

Pasal 20 ayat (1) UUPA menyatakan bahwa Hak Milik adalah hak turun-temurun, terkuat dan terpenuh yang dapat dipunyai orang atas tanah, dengan mengingat ketentuan Pasal 6 UUPA yakni mengenai fungsi sosial dari setiap hak atas tanah. Sebagaimana ditegaskan juga pada Pasal 32 PP No. 24 tahun 1997:

(1) Sertipikat merupakan surat tanda bukti hak yang berlaku sebagai alat pembuktian yang kuat mengenai data fisik dan data yuridis yang termuat di dalamnya, sepanjang data fisik dan data yuridis tersebut sesuai dengan data yang ada dalam surat ukur dan buku tanah hak yang bersangkutan.

(2) Dalam hal atas suatu bidang tanah sudah diterbitkan sertipikat secara sah atas nama orang atau badan hukum yang memperoleh tanah tersebut dengan itikad baik dan secara nyata menguasainya, maka pihak lain yang merasa mempunyai hak atas tanah itu tidak dapat lagi menuntut pelaksanaan hak tersebut apabila dalam waktu 5 (lima) tahun sejak diterbitkannya sertipikat itu telah tidak mengajukan keberatan secara tertulis kepada pemegang sertipikat dan Kepala Kantor Pertanahan yang bersangkutan ataupun tidak mengajukan gugatan ke Pengadilan mengenai penguasaan tanah atau penerbitan sertipikat tersebut.

Penjelasan Pasal 32 ayat (1) PP Nomor 24 tahun 1997 tersebut menyatakan: bahwa Sertipikat merupakan tanda bukti yang kuat, dalam arti bahwa selama tidak dapat dibuktikan sebaliknya data fisik dan data yuridis yang tercantum di dalamnya harus diterima sebagai data yang benar. Sudah barang tentu data fisik maupun data yuridis yang tercantum dalam sertipikat harus sesuai dengan data yang 
tercantum dalam buku tanah dan surat ukur yang bersangkutan, karena data itu diambil dari buku tanah dan surat ukur tersebut.

\subsection{Rumusan Masalah}

Berdasarkan uraian latar belakang di atas, maka rumusan masalah yang dapat peneliti sampaikan adalah sebagai berikut :

1. Bagaimanakah pelaksanaan Pendaftaran Tanah Pertama Kali Secara Sporadik Melalui Pengakuan Hak?

2. Bagaimanakah Kekuatan dan Kepastian Hukum Sertipikat Yang Diterbitkan Melalui Pengakuan Hak?.

\section{METODE PENELITIAN}

Jenis dari penelitian ini adalah deskriptif komparatif yaitu memaparkan keadaan-keadaan yang nyata dalam praktek kemudian mencoba membandingkan dengan peraturanperaturan yang ada hubungannya dengan masalah tersebut, Dengan penelitian yang bersifat deskriptif komparatif diharapkan dapat diperoleh gambaran tentang data faktual yang berhubungan dengan Pendaftaran Tanah Pertama Kali Secara Sporadik Melalui Pengakuan Hak Pada Kantor Pertanahan Kabupaten Lamongan.

\section{HASIL DAN PEMBAHASAN}

a. Pengertian Pendaftaran Tanah :

Berdasar pasal 19 ayat (2) Undang Undang Nomor 5 Tahun 1960 dinyatakan bahwa Pendaftaran Tanah tersebut dalam ayat (1) pasal ini meliputi:

1) pengukuran, perpetaan dan pembukuan tanah;

2) pendaftaran hak-hak atas tanah dan peralihan hak-hak tersebut;

3) pemberian surat-surat tanda bukti hak yang berlaku sebagai alat pembuktian yang kuat.
Menurut pasal 1 Peraturan Pemerintah Nomor 24 Tahun 1997:

"Pendaftaran Tanah adalah rangkaian kegiatan yang dilakukan oleh Pemerintah secara terus menerus , berkesinambungan dan terarur, meliputi pengumpulan, pengolahan, pembukuan dan penyajian serta pemeliharaan data fisik dan data yuridis, dalam bentuk peta dan daftar, mengenai bidang-bidang tanah dan satuan-satuan rumah susun, termasuk pemberian surat tanda bukti haknya bagi bidang-bidang tanah yang sudah ada haknya dan hak milik atas atas satuan rumah susun serta hak-hak tertentu yang membebaninya".

\section{b. Pendaftaran Tanah Pertama Kali Secara Sporadik. \\ Definisi Pendaftaran Tanah Secara} Sporadik berdasar Peraturan Pemerintah Nomor 24 Tahun 1997 Pasal 1 angka 11 adalah kegiatan pendaftaran tanah untuk pertama kali mengenai satu atau beberapa objek pendaftaran tanah dalam wilayah atau bagian wilayah suatu desa/kelurahan secara individual atau massal, berarti pula seluruh biaya dibebankan kepada pemohon.

\section{c. Permohonan pendaftaran tanah sporadik}

Kegiatan awal pendaftaran tanah secara sporadik dilakukan atas permohonan pemegang hak yang bersangkutan, diantaranya:

a. permohonan pengukuran

b. permohonan pendaftaran hak baru

c. permohonan pendaftaran hak lama

d. permohonan pendaftaran peralihan hak dan lain-lain.

Permohonan pengukuran bidang tanah diajukan untuk keperluan :

a. persiapan permohonan hak baru

b. pemecahan, pemisahan dan penggabungan bidang tanah

c. pengembalian batas

d. pemetaan batas dalam rangka konsolidasi tanah

e. inventarisasi pemilikan dan penguasaan tanah dalam rangka pengadaan tanah sesuai ketentuan yang berlaku.

f. lain-lain keperluan dengan persetujuan pemegang hak

d. Arti Kepastian Hukum 
Ketentuan jaminan kepastian hukum tercantum dalam Penjelasan Umum Undang-Undang Republik Indonesia Nomor 5 Tahun 1960 tentang Peraturan Dasar Pokok-Pokok Agraria (untuk selanjutnya disebut UUPA) yang pada intinya menyatakan bahwa "karena bagi rakyat asli hukum agraria penjajahan itu tidak menjamin kepastian hukum, maka perlu adanya hukum agraria baru yang Nasional, yang akan mengganti hukum yang berlaku sekarang ini, yang tidak lagi bersifat dualisme, yang sederhana dan yang menjamin kepastian hukum bagi seluruh rakyat Indonesia".

Lebih detail lagi jaminan kepastian hukum ditegaskan dalam UUPA pasal 19, pasal 23, pasal 32, pasal 38 yang intinya menyatakan bahwa pendaftaran tanah dilaksanakan untuk menjamin kepastian hukum dengan menerbitkan surat tanda bukti hak yang berlaku sebagai alat pembuktian yang kuat atas kepemilikan tanah.

\section{e. Penentu Jaminan Kepastian Hukum}

Sebagaimana dijelaskan pada Bab II, bahwa tujuan pendaftaran tanah adalah untuk memberikan kepastian hukum dan perlindungan hukum kepada pemegang hak atas tanah, pemilik satuan rumah susun, dan pemegang hak tanggungan. Disamping itu, juga dimaksudkan untuk menyediakan informasi kepada pihak yang berkepentingan dan Pemerintah untuk memperoleh data tentang sebidang tanah, serta untuk terselenggaranya tertib administrasi pertanahan.

Pasal 23 ayat (1) UUPA menyatakan: "Hak Milik, demikian pula setiap peralihan, hapusnya, dan pembebanannya dengan hak-hak lain harus didaftarkan menurut ketentuanketentuan yang dimaksud dalam Pasal 19". Menurut Penjelasan Umum IV UUPA, Pasal 23 ini ditujukan kepada pemegang Hak Milik, dengan maksud agar mereka memperoleh kepastian tentang haknya itu; sedangkan Pasal 19 ditujukan kepada Pemerintah sebagai suatu instruksi, agar di seluruh wilayah Indonesia diadakan pendaftaran tanah yang bersifat 'rechts kadaster' (yang menjamin kepastian hukum).

Selanjutnya, Pasal 23 ayat (2) UUPA menyatakan: "Pendaftaran termaksud dalam ayat (1) merupakan alat pembuktian yang kuat mengenai hapusnya hak milik serta sahnya peralihan dan pembebanan hak tersebut".

Sebagaimana ditegaskan dalam Pasal 19 ayat (2) c UUPA bahwa dalam rangkaian pendaftaran tanah, akhir dari proses pendaftaran tanah adalah 'pemberian surat-surat tanda bukti hak' sebagai alat pembuktian yang kuat.

Yang dimaksud dengan 'alat bukti yang kuat' dalam hal ini adalah bahwa selama tidak dapat dibuktikan sebaliknya, data fisik dan data yuridis yang tercantum di dalam alat bukti itu harus diterima sebagai data yang benar, baik dalam melakukan perbuatan hukum sehari-hari maupun dalam berperkara di pengadilan. Sudah tentu data fisik dan data yuridis yang tercantum dalam sertipikat harus sesuai dengan data yang tercantum dalam surat ukur dan buku tanah tersebut. Dalam hubungan ini, maka data yang dimuat dalam surat ukur dan buku tanah itu mempunyai sifat terbuka untuk umum, sehingga pihak yang berkepentingan (bahkan PPAT) dapat mencocokkan data dalam sertipikat itu dengan yang ada dalam surat ukur dan buku tanah yang disajikan di Kantor Pertanahan.

Perlu diperhatikan, bahwa menurut PP 10 Tahun 1960 Surat Ukur merupakan bagian dari sertipikat dan merupakan petikan dari peta pendaftaran, sehingga data yuridisnya harus sesuai dengan peta pendaftaran sedangkan menurut PP No. 24 Tahun 1997, Surat Ukur merupakan dokumen yang mandiri di samping peta pendaftaran. Surat ukur 
memuat data fisik bidang tanah hak yang bersangkutan. ${ }^{1}$

Namun demikian, keberadaan sertipikat masih tetap terbuka untuk dibantah mengingat stelsel publikasi dari pendaftaran tanah yang dianut Indonesia adalah stelsel negatif, yang kebenaran data yang disajikan tidak dijamin oleh negara. Penjelasan Pasal 32 ayat (2) PP 24 Tahun 1997 menyatakan bahwa kelemahan sistem publikasi negatif adalah, bahwa pihak yang namanya tercantum sebagai pemegang hak dalam buku tanah dan sertipikat selalu menghadapi kemungkinan gugatan dari pihak lain yang merasa mempunyai tanah itu. Umumnya kelemahan tersebut diatasi dengan menggunakan lembaga acquisitive verjaring atau adverse possession. Hukum tanah kita yang berdasarkan hukum adat tidak dapat menggunakan lembaga tersebut, karena hukum adat tidak mengenalnya. Tetapi di dalam hukum adat terdapat lembaga yang dapat digunakan untuk mengatasi kelemahan sistem publikasi negatif dalam pendaftaran tanah, yaitu lembaga rechtsverwerking.

\section{PENUTUP}

\subsection{KESIMPULAN}

1. Pendaftaran Tanah Pertama Kali atas tanah adat menurut ketentuan PP No. 24 Tahun 1997 adalah sebelum didaftarkan harus dikonversi terlebih dahulu, baik secara sistematis maupun sporadik. Melalui lembaga konversi hak-hak atas tanah yang ada sebelum berlakunya UUPA disesuaikan dengan hak yang ada di UUPA. Terhadap hak atas tanah adat yang memiliki bukti-bukti tertulis atau tidak tertulis dimana pelaksanaan konversi dilakukan oleh Panitia Pendaftaran Ajudikasi yang bertindak atas nama Kepala Kantor Pertanahan untuk sistematik atau dilakukan oleh Kepala Kantor Pertanahan untuk sporadik, prosesnya dilakukan dengan penegasan hak sedangkan terhadap hak atas tanah adat yang tidak mempunyai bukti dilakukan dengan proses pengakuan hak.

2. Dalam rangkaian pendaftaran tanah pertama kali, akhir dari proses pendaftaran tanah adalah pemberian surat-surat tanda bukti hak yang umum disebut "sertipikat" sebagai alat bukti hak yang kuat. Jaminan kekuatan dan kepastian hukum sertipikat yang diterbitkan melalui pengakuan hak sama dengan sertipikat yang diterbitkan melalui konversi maupun penegasan, sebagaimana ditegaskan dalam Pasal 19 dan pasal 23 UUPA dan Pasal 32 ayat (2) PP 24 Tahun 1997 sepanjang data fisik dan data yuridis yang tercantum dalam sertipikat adalah data yang benar dan tidak dapat dibuktikan sebaliknya.

\subsection{SARAN}

1. Dengan berlakunya PP No. 24 Tahun 1997 hendaknya pendaftaran tanah di Indonesia khususnya di Kabupaten Lamongan yang dilakukan secara masal melalui PRONA bukan diutamakan di daerah perkotaan tetapi hendaknya dilakukan di desa terutama desa-desa yang tingkat ekonominya lemah.

2. Perlu penyuluhan hukum yang sifatnya terpadu yang dilakukan pihak Badan Pertanahan Nasional secara berkala sehingga masyarakat semakin mengerti pentingnya sertifikat sebagai alat pembuktian yang kuat.

3. Agar supaya pemasyarakatan UUPA terus dilakukan sehingga masyarakat mengetahui secara baik tentang peraturan pertanahan.

\section{DAFTAR PUSTAKA}

\section{A. BUKU-BUKU}

Badan Pertanahan Nasional, 1997. Hasil Rapat Kerja Kantor Menteri Negara Agraria dan Badan Pertanahan Nasional, Jakarta 2-5 Maret 1997 
Harsono, Boedi. 2006. Hukum Agraria Indonesia Himpunan PeraturanPeraturan Hukum Tanah, Cetakan Kelima belas, Djambatan, Jakarta.

Moleong, Lexy J., 1993. Metodologi Penelitian Kualitatif. Remaja. Rosdakarya, Bandung.

Noer Fauzi, 2001. Pengakuan Sistem Penguasaan Tanah Masyarakat $\underline{\text { Adat }}$, Jakarta, Bhumi Bhakti,

Soeprapto, 1986. Undang-Undang Pokok Agraria Dalam Praktek, Jakarta,

\section{B. UNDANG - UNDANG \\ Undang -Undang Dasar Republik Indonesia Tahun 1945; \\ Undang-Undang Nomor 5 tahun 1960 tentang Peraturan Dasar Pokok- Pokok Agraria, (Lembaran Negara Tahun 1960 Nomor 104, Tambahan Lembaran Negara Nomor 2043). \\ Peraturan Pemerintah Nomor 24 tahun 1997 tentang Pendaftaran Tanah, (Lembaran Negara Tahun 1997 Nomor 59, Tambahan Lembaran Negara Nomor 3696). \\ Peraturan Menteri Negara Agraria/Kepala Badan Pertanahan Nasional Nomor 3 tahun 1997 tentang Ketentuan Pelaksanaan Peraturan Pemerintah Nomor 24 tahun 1997 tentang Pendaftaran Tanah.}

\section{Website}

http://www.situsindonesia.com/detail/kamus-besarbahasa-indonesia-online.html 